\title{
Exploring faculty experiences with e-books: a focus group
}

\begin{abstract}
Purpose: In spring of 2007, Arizona State University Libraries held a focus group of selected faculty to discover their perceptions and use of electronic books (e-books) in their research and teaching.

Methodology/approach: We employed the services of the Institute of Social Sciences Research to recruit and moderate the focus group. The following major themes were explored: 1) use of e-books as textbooks; 2) use of e-books for personal research; 3) comparison between e-books and print; 4) disciplinary differences in perceptions of ebooks; and 5) motivators for future use.
\end{abstract}

Findings: Overall, the focus group revealed that faculty had generally unsatisfactory experiences in using e-books in their research and teaching due to the unreliability of access, lack of manipulability, and the steep learning curve of the various interfaces. However, most faculty agreed that e-books would be a very viable and useful alternative if these issues were resolved.

Research limitations/implications: The focus group consisted of only six faculty members and hence is not representative of faculty as a whole. A larger survey of a more diverse faculty population would greatly serve to clarify and expand upon our findings.

Practical implications: The implications for academic libraries include providing better outreach and training to faculty about the e-book platforms offered, provide better course support, and advocate to e-book vendors to consider faculty's teaching and research needs in their product development.

Originality/value of paper: To the best knowledge of the authors, this is the first published study of faculty opinions and use of e-books utilizing focus group methodology and offers detailed information that would be useful for academic libraries and e-book vendors for evidence-based decisions.

Keywords: electronic books, faculty, focus group

Category: Research Paper

\section{INTRODUCTION}

Classified by the Carnegie Foundation as a Research I institution, Arizona State University (ASU) has been undergoing massive growth in the last decade and is now one of the largest universities in the nation in terms of enrollment. In the Fall 2007 semester, 
ASU enrolled nearly 65,000 students. ASU has been working towards a new model of higher education, a "New American University," defined as "a single, unified institution comprising four differentiated campuses that positively impact the economic, social, cultural and environmental health of the community it serves." (Office of the President, 2007) This "unified institution" approach has a significant impact on library collections and services. Arizona State University (ASU) Libraries consist of eight libraries distributed over four different campuses in the Phoenix metropolitan area. While there are distinct programs at each campus, there is considerable overlap of library collections due to the multi-disciplinary nature of today's academic and research world. Librarians on all campuses find themselves not only collecting materials that target the programs on their campus, but also relying on rapid access and circulation of shared resources between multiple campuses to supplement coverage in interdisciplinary areas. In addition to four physical campuses, ASU Libraries also support over 20 online degree and extended education programs targeting both undergraduate and graduate students. Print resources cannot satisfy the access needs of this large and growing population of distance learners, no matter how many copies are available.

Impeding our ability to use a simple multiple copy solution, library budgets continue to be increasingly stagnant. We do not have excess funds to purchase multiple copies while still keeping current with new publications and meeting the curriculum and research needs of our students and faculty. If a choice must be made between purchasing a duplicate copy of a book or a new book title that is critical to supporting a faculty's curriculum or student assignments, purchasing the new title takes priority. It is an ongoing struggle for libraries to find a balanced method of meeting the competing needs of users.

Because of these factors the ASU Libraries have been aggressively collecting electronic books (e-books) since 2000 from several vendors, including NetLibrary, MyiLibrary, Ebrary, Safari, Knovel, and STAT!Ref, as well as from other providers that include ebooks in their electronic collections. As of December 2006, the libraries provided access to over 30,000 electronic books. The libraries have purchased e-books both as package deals by subject or publisher through a provider as well as selecting title-by-title. The ASU Libraries continuously work to streamline the acquisitions process for e-books, as a result, e-books can be purchased using the same ordering process used for print acquisitions for a few select vendors.

Due to the ever increasing availability of new and cost effective e-book packages from major publishers and to our growing reliance on e-books to solve access problems for multiple campuses and distance learners, ASU Libraries decided to collect information to give us a better understanding of how our patrons use e-books, including collecting statistics from vendors and user surveys. While surveys are a useful method for gathering information from a large population, they must be carefully written and administered in order to ensure that the data gathered is valid, and responses are often too vague or general to be relevant to decision making in a particular library setting.

Additionally, it is difficult to ask follow-up questions once a survey has been taken. We wanted to explore, in detail, faculty perceptions and experiences with e books, attempt to 
flesh out disciplinary differences, if any, and discover barriers to the adoption of ebooks. A focus group seemed to be the best option for exploring in depth our faculty's experiences with and opinions of e-books. Although focus groups aren't generalizable due to their small sample size, they do give the opportunity to ask follow-up questions, gather clarification on responses, and allows participants to interact and expand on answers through interaction and moderation.

\section{LITERATURE REVIEW}

A search of the literature revealed that faculty use and perceptions of e-books have only been explored in surveys. In-depth, qualitative data providing a comprehensive picture of the faculty experience, attitude, perception, and expectations related to e-books were not found. Most of the research on this topic surveyed students, faculty, or both. Only one study utilized a focus group to gather data, but focused on a particular group of students. This discovery made it clear that a focus group of faculty could be a valuable contribution.

The primary consensus among the published literature is that faculty still prefer print books over electronic books for research, leisure reading, and textbooks, as found by Walton (2007) using a small sample $(\mathrm{n}=25)$ of faculty at a liberal arts university. Cox had similar findings in 2004 when over $63 \%$ of his respondents disagreed that electronic books were easier to read than print books, and over $51 \%$ of respondents reported that they print from electronic books rather than read online. Findings from the recent global survey of faculty conducted by Ebrary (2007) agree; 79\% of faculty stated that they prefer print books when reading a whole book or extensive sections. Even though print still seems to be the preferred format, faculty do have some awareness of and experience with e-books. A larger survey involving 258 faculty members discovered that most faculty had only used e-books once or occasionally. Very few (11.9\%) used them frequently. (Levine-Clark, 2006).

When faculty do use e-books, they are very task-oriented (Table 1). Levine-Clark's (2006) survey showed that faculty tend to read a chapter or article (47.9\%) or a single entry/few pages (42.5\%) instead of reading an entire e-book (9.6\%). Elsewhere faculty responded that they used e-books for research monographs, reference works and textbooks more often than for pleasure reading (Rowlands, 2007). Ebrary's recent worldwide survey of faculty (2007) found that $53 \%$ of faculty use e-books for research, class preparation or instruction. Similarly, Cox (2004) found that lecture preparation was the most popular reason faculty used e-books (65\%), followed by academic research (56\%). Faculty also integrate e-books into their courses either through actively encouraging students to use e-books (42\%), using e-book chapters or sections for course readings (28.5\%), or linking to e-books inside of course management software (16.6\%) (Ebrary, 2007). Anuradha \& Usha (2006) discovered in their survey at the Indian Institute of Science that the most used types of e-books were reference materials (83\%) and technical books (80\%). This pattern of practical usage makes sense in light of the fact that the quality faculty like most about e-books is their search tools, as found by both Cox (2004) and Anaradha \& Usha (2006). 
Faculty have identified several disadvantages, weaknesses and uncertainties about ebooks. Cox (2004) finds that faculty are least sure about downloading, printing, bookmarking, and emailing content, and the faculty at the Indian Institute of Science state that the most common reason (22\%) they do not use e-books is that they are hard to read and browse (Anaradha \& Usha, 2006). Other disadvantages include eye strain due to reading online and the difficulty of navigating an online book (Levine-Clark, 2006). Responding to the question of what would make e-book usage more suitable, faculty reported that having a larger collection of e-books (55.8\%), the ability to download (52.4\%), the ability to print and copy with fewer restrictions (49.9\%), would make e-books more attractive (Ebrary, 2007).

Table 1.

FACULTY USE OF E-BOOKS

\begin{tabular}{|c|c|c|}
\hline USE & $\begin{array}{l}51.3 \% \text { had ever used an e- } \\
\text { book (Levine-Clark, 2006) }\end{array}$ & $\begin{array}{l}\text { Approximately 53\% use e- } \\
\text { books for research, class } \\
\text { preparation, or instruction } \\
\text { (Ebrary, 2007) }\end{array}$ \\
\hline REASON FOR USE & $\begin{array}{l}\text { Lecture preparation (65\%), } \\
\text { academic research }(56 \%) \\
(\text { Cox, 2004) }\end{array}$ & \\
\hline TYPE OF USE & $\begin{array}{l}\text { Read chapter or article } \\
(47.9 \%), \\
\text { Read single entry/few pages } \\
(42.5 \%), \text { Read entire book } \\
(9.6 \%) \\
\text { (Levine-Clark, 2006) }\end{array}$ & \\
\hline $\begin{array}{l}\text { TYPE OF E-BOOKS } \\
\text { CONSULTED }\end{array}$ & $\begin{array}{l}\text { Research monographs } \\
\text { (59.5\%, reference works } \\
\text { (56.1\%), textbooks (55.4\%) } \\
\text { (Rowlands, 2007) }\end{array}$ & $\begin{array}{l}\text { Reference materials } \\
\text { (83.3\%), technical books } \\
(80 \%) \text { (Anuradha and Usha, } \\
2006)\end{array}$ \\
\hline $\begin{array}{l}\text { DISADVANTAGES OF E- } \\
\text { BOOKS }\end{array}$ & $\begin{array}{l}\text { Hard to read and browse } \\
\text { (Anaradha \& Usha, 2006) }\end{array}$ & $\begin{array}{l}\text { Eye strain, navigation } \\
\text { (Levine-Clark, 2006) }\end{array}$ \\
\hline $\begin{array}{l}\text { ADVANTAGES OF E- } \\
\text { BOOKS }\end{array}$ & $\begin{array}{l}\text { Ability to search, } \\
\text { convenience, suitability for } \\
\text { reading brief passages } \\
\text { (Levine-Clark, 2006) }\end{array}$ & \\
\hline
\end{tabular}

Understanding disciplinary differences in attitude toward and use of e-books would be very useful for collection development purposes. However, the review of the literature does not seem to find any statistically significant differences. Levine-Clark (2006) discovered that social scientists at the University of Denver had a slightly higher rate of e-book usage (57.1\%) than other disciplines, which fell in the 51-54\% range. Levine-Clark (2007a) found some differences in terms of frequent use; the humanities 
(13.8\%), business (13.3\%) and social science (13\%) faculty were more frequent users of e-books than science faculty (11.8\%).

A later study compared e-book usage of humanities faculty and students to the overall university population (Levine-Clark, 2007b). Although humanists possessed a greater awareness of e-books compared to faculty and students as a whole, their use of e-books was not greater (52.3\% of humanists had ever used an e-book while $51.3 \%$ of university as a whole had used one). In addition, humanists had the lowest level of frequent e-book usage (7.3\% compared to $10.3 \%$ for the university as a whole) and they preferred print books over e-books at a rate higher than other disciplines (27.2\% vs. $16.6 \%)$.

There are several studies addressing student use (Table 2), and it is interesting to note similarities and differences between student and faculty perceptions of e-books. Chu (2003) conducted a small survey of library science students and found that only a third of them had used e-books. The most common reason that e-books were not used was they were hard to read and browse. Conversely, the most common reasons respondents used ebooks were their availability and that they were searchable. A study of undergraduate computer science and IT students at University of Malaya found that $61 \%$ had not used ebooks, and that $81.1 \%$ preferred print books over electronic books. However those that use e-books cited that availability online, fast access, and not having to make a visit to the physical library were important reason for using e-books (Ismail and Zainab, 2005). A focus group of undergraduate midwifery students conducted after instruction on how to access e-books found that students saw more disadvantages than advantages with ebooks. The primary disadvantages cited were accessibility issues (one user at a time per book), navigation, and limited number of titles (Appleton, 2004).

Table 2.

STUDENT USE OF E-BOOKS

\begin{tabular}{|l|l|l|l|}
\hline USE & $\begin{array}{l}\text { REASONS FOR } \\
\text { USING }\end{array}$ & $\begin{array}{l}\text { REASONS FOR } \\
\text { NOT USING }\end{array}$ & RESEARCHER \\
\hline $\begin{array}{l}\text { 33.3\% had used e- } \\
\text { books }\end{array}$ & $\begin{array}{l}\text { Availability, } \\
\text { searchable }\end{array}$ & $\begin{array}{l}\text { Hard to read and } \\
\text { browse }\end{array}$ & Chu (2003) \\
\hline $\begin{array}{l}\text { 39\% had used e- } \\
\text { books }\end{array}$ & $\begin{array}{l}\text { Available online, fast } \\
\text { access, didn't have to } \\
\text { visit physical library }\end{array}$ & $\begin{array}{l}\text { Prefer to read print or } \\
\text { prefer to use websites }\end{array}$ & $\begin{array}{l}\text { Ismail and } \\
\text { Zainab (2005) }\end{array}$ \\
\hline
\end{tabular}




\section{METHODOLOGY}

Shoaf (2003) discusses the value of using a skilled professional moderator instead of library staff to conduct a focus group. He advised that libraries often lack the expertise, facilities, and dedicated staff to run a focus group. Based on this advice, we agreed that contracting a third party to conduct the focus group would ensure a more neutral session and prevent library staff from influencing the course of the focus group or trying to teach or inform during the session. To this end, ASU Libraries enlisted the Institute for Social Sciences Research (ISSR), an ASU based organization, to recruit participants and moderate the focus group at their facility.

The purpose of the focus group was to learn about faculty perceptions and experiences with electronic resources available through ASU Libraries. ASU librarians and administrators submitted a list of questions to the focus group moderator who used them as the basis for focus group discussion and follow up questions. For our research, we designed questions to illicit feedback on several topics related to e-books. The questions on e-books occupied about half of the focus group's total time, and are included in the Appendix.

Participants were recruited by ISSR using a random selection process from all schools and as many departments as possible using the ASU online directory and based on our request to include a diversity of disciplines and professorial ranks. Those selected were emailed an invitation to the group. Each participant was offered a \$35 mall gift certificate as an incentive. A total of eight participants were recruited but six actually attended the focus group. The participants represented the following fields: political science, history, graphic design, industrial design, marketing, and bioengineering. A range of faculty ranks were represented including assistant, associate and full professors. The focus group was held for 90 minutes in the ISSR's state-of-the-art facility which included a conference room with two cameras, and an observation room. The group was facilitated by the ISSR moderator, who was neither a librarian nor affiliated with the library. The focus group was recorded and librarians observed behind a one way mirror in the observation room. After the focus group session, the ISSR provided a complete transcript and a copy of the recorded session to ASU Libraries with which we have used, along with our own notes.

\section{RESULTS}

Our first question was a general inquiry into the participants' familiarity with e-books. The participants expressed mostly negative responses: "There's a number of different experiences I've had...one was having to use the falsehood of having to check out an online-book, it was really silly." Another professor agreed, saying: "I think it’s the technical difficulties of trying to deal with it that put me off of trying to use that type of materials in class." Another mentioned that using e-books was "very tedious, and it wasn't worth the time." 
After reviewing the session recording and the transcript, several themes emerged which we have broken into the following general categories: using e-books as textbooks in class, using e-books for research, a comparison between e-books and print, differences in use between various disciplines, and possible motivations for using e-books in the future.

\section{E-BOOKS AS TEXTBOOKS}

When faculty were asked if they use e-books as class textbooks, only the history and industrial design professors replied that they had. According to both, one of the primary concerns with using e-books as textbooks was the question of reliability. The history professor said that you could never be certain whether the students could get into the ebook and that "as an instructor you know that there's that moment when something's due and if three or four [students] say 'oh I couldn't get in', what are you going to say? 'Hey, you're up the creek?' So if you don't want that type of thing to happen, you just don't give them the opportunity and e-books are the opportunity for that." The industrial design professor tried to avoid this concern by teaching the students how to access the ebook at the start of class, but still received complaints from the students about the difficulties of using e-books. She said that the limitations imposed on viewing e-books are particularly frustrating: "It will only let you look at a certain percentage of pages at a time and then your time is up and you have to login [after] another 24 hours.....That, to me, is mind-boggling, because it's being deliberately built into the system and that it's the fallacy of the previous system" [referring to print books].

Another professor said she would never suggest an e-book as a textbook for her large undergraduate lecture class because "if it didn't work out it would be mass chaos". However she mentioned she might try it with a small graduate or upper division class. After some discussion and comparison, several professors thought that using e-books in class would be more successful with more experienced students, such as seniors or

graduate students. When discussing the difficulties of differing levels of expertise among students depending on age, technical experience, and distance, the graphic design professor mentioned that she expected "there will be a pretty rapid transition over the next few years." The history professor responded to this by saying, "Once they start using [e-books] in high schools, then the whole ballgame will change."

In some disciplines e-books are not feasible as textbooks because they do not reproduce the content accurately. For example, in graphic design, "you are losing a lot of information and content with the colored plates"[in e-books]. Instead the professor likes to bring these books to class to be passed around so the students can see the detailed illustrations and plates.

\section{E-BOOKS FOR RESEARCH}

Only the industrial design faculty member uses e-books regularly for research, and does so when she wants to "dip in and out of" a book. The graphic design professor said that ebooks are not readily available in her field (and not suitable due to the reproduction of 
images problem mentioned above); however she finds them more useful when she's looking for information outside of her field.

\section{E-BOOKS VERSUS PRINT BOOKS}

We wondered how professors would compare e-books to their print equivalents. Predictably, many professors expressed great affection for print books, one saying, "I'm a really old fashioned guy and I like-books that open up and that you can read in the bath, and read while you're in bed." Other reasons for preferring the print version of a book included the tactile sense of books, and the fact that print books are more versatile for taking notes and making annotations in the document itself. Interestingly, many participants believed that print books, along with the knowledge of the anatomy of a book, could aid in recall and learning; "Physical books help with their visual memories as well, it's easier to remember where, just visually how you think, of where I read that piece of information; it was near the front, so it was an introductory idea." Additionally, professors mentioned that students' study habits, such as staring at a problem and flipping back to another page, as well as the possibility for a serendipitous discovery while browsing through the pages of books rather than doing a search or clicking through pages, could be a consideration when making a decision whether to use e-books. They weren't sure those experiences would transfer to an e-book. The history professor said that while he doesn't mind trying to use e-books, the rest of his colleagues wouldn't "trust the experience of reading a screen, no matter what you say," indicating a definite bias against e-books. The two design professors agreed that while e-books might be useful to some aspects of their work, there is a definite loss of content when it comes to graphics.

One professor mentioned that he would start with an e-book when given a choice between electronic and print if it were convenient, but might still go check out the print book depending on what he needed; "[If] there was a book that showed up as both a print copy and an electronic copy, I'm not even going to bother checking it out, I'll take a look at it online...though, again, it's a trade-off on whether you can just capture the parts that you want and download them. With a live book... you can photocopy the pages that you need... and you don't have the ability to do that with an e-book." Similarly, the marketing professor suggested that e-books could be very useful for her program, "My students would go bananas if I told them to come to the library and get a book... [they] are at these remote locations that they aren’t about to come to the library."

Some professors use e-books to help generate interest in print books amongst their students, "I've often seen students...they look at it online...a couple weeks later you see they've gone out and bought it to add to their personal collection." Additionally, the professors are interested in students being able to access e-books at the end of a semester, or after the completion of a course: "If you teach a particular book in class and two years later the student can easily retrieve that if the bibliography is all hyper-linked online."

One professor suggested that a possible argument for using e-books is that they are more ecologically friendly than print by saving paper: "Maybe you could tie them into the sustainability initiative as well...to try to have our impact be carbon neutral, which you do 
have to move from print." Other professors agreed that this argument would appeal both to professors and students.

\section{DISCIPLINARY DIFFERENCES}

The history and design faculty had the most experience using e-books, despite the history professor's comment that many of his colleagues were hoping to retire before being forced to use e-books. The design professors said they're not very book-focused: "We're equal opportunity, we'll take anything, you know." The one science professor had not used them at all but would be apt to try if someone made a case for them: "Otherwise I won't argue [for] it until somebody says 'you gotta do this, it’s really the way to go."'

One factor that may have an effect on the use of e-books in different disciplines is the price of textbooks: "I think it depends on the discipline. Textbooks in the natural sciences are very expensive... in the social sciences and humanities, not nearly as much." Several of the professors indicated an interest in saving their students some money, and would be more likely to use e-books if offered as a less expensive alternative to textbooks.

As a point of contrast, the marketing professor thought that primary reason her students and faculty would be interested in using e-books was the time-saving element and accessibility, rather than expense: "I think the School of Business would be very open to e-books because...I think we are pretty open to being technologically advanced, we do have a ton of online programs also with students all over the world. So yeah I think we would be very open...it's all about time saving. I don't want to say that money is not important, but in general, to our students, it's not as important as time."

\section{MOTIVATORS}

When asked what would make them more interested in using e-books, most faculty talked about looking past the print equivalent: "A lot of e-books are directly scanned from the actual book itself so they aren't taking advantage of the fact that it's online and can be hyper-linked...it should be interlinked and hyper-linked and referenced to other materials that are out there." Additionally, professors wanted, both for themselves and for their students, the same freedoms allowed by print books: the ability to write notes, link to related items or citations, highlight passages, and copy and paste from the text. In other words, to use the e-book in a practical way for research and scholarship: "the manipulation of the information I think is key...if it's just a page on the screen, you can't write...chop off this paragraph here, highlight this paragraph here or write 'the professor says this is wrong' there. I think, for students, that is a really important step in the studying process."

Some professors mentioned that books with additional content, such as supplements on a CD-ROM, would be perfect examples of how e-books could actually be an improvement over the print equivalent, if the media content could be integrated with the actual text of the book. A simple formatting consideration that improves the readability of e-books 
mentioned by the marketing professor was the need to use fonts with serifs: "I hate to hit that theme, but it really makes a difference when you are reading on a screen. You have to have serif type." The professor from graphic design was very appreciative of this: "As a graphic designer, I love it that you know that!"

Most professors agreed that the primary factor that would increase their interest and use in e-books would be the ability to trust that the e-book would be reliable and accessible to themselves and their students, whenever they needed it. Their current experiences have not given them cause to believe that this is currently the case, and they are unlikely to explore the option further without positive experiences regarding reliable accessibility and interactivity in the future.

\section{CONCLUSIONS}

Anecdotal information from our colleagues has led us to believe that science and engineering faculty are more likely to use e-books than humanities and social science faculty, though the surveys done by Levine-Clark (2006, 2007a) do not indicate a statistically significant difference. This was also not the case in our focus group, where the history and design faculty were the most experienced with e-book usage. One factor that may contribute to this discovery, however, is that the age and academic rank of the participants of our study was not representative, despite our efforts to find participants across a broad spectrum of ranks and disciplines. For example, there were no Assistant Professors from scientific fields represented, which could account for the lack of an ebook preference in that field. A larger survey of a more diverse faculty population would greatly serve to clarify and expand upon our findings, as well as provide a more representative sample for future research.

Like most focus groups, the small size of our sample and the self-reporting techniques used would make any generalization to a larger population of faculty suspect.

Additionally, participants in the focus group were self-selecting in responding to the call for recruitment, and a few mentioned that they had responded due to their interest in the library, rather than the gift card incentive. Besides size, another limitation of our study was the lack of distinction between e-book packages when we inquired about perceptions and use. However, many of the features of the different e-book packages were mentioned by the participants when speaking about the limitations of e-books, such as having to "check-out" an e-book in NetLibrary or downloading specific software for Ebrary's proprietary reader. Faculty were surprised to learn from the moderator that the e-book vendors rather than the library set these limitations.

If academic libraries are increasingly turning to e-books as an alternative to purchasing multiple copies, it's important that they understand how e-books are perceived and used by our faculty. Professors are vitally important in increasing the use of any new teaching or research technology due to their primary responsibility of educating the students. Consequently, the endorsement and use of new resources by university faculty is critical. Our focus group reveals that while faculty are open to the concept of using e-books, their experiences have not been positive. The limitations of e-book accessibility and practical 
use cannot be overlooked at this time. Faculty are especially cautious about using them as textbooks or for course readings due a perceived learning curve for their students and believing that the technology is too unreliable, which has been proven by their own experiences. They also feel that trying to use them in class, as well in their own research, is tedious and time-consuming. Were these issues resolved, particularly with respect to accessibility and interactivity, most faculty would be willing to use them. Professors are very interested in being able to manipulate and link information in an online environment, both for their personal use as well as teaching purposes, and if e-books could be incorporated into these networks of information they would be very useful. As the number of online course offerings and distance learners continue to grow, faculty increasingly face the need to find new ways of providing course materials. Several professors mentioned this aspect during the focus group and implied they would like to be able to look to e-books to serve this need.

In addition to marketing e-books to faculty and students, academic librarians have a responsibility to advocate the needs of their users to e-book vendors to consider when planning future product development. Without the input of libraries, e-book vendors' primary clientele, there is no guarantee that the necessary improvements in usability, accessibility, and interactivity would ever be made. E-books have the potential to serve a very real need, and together e-book vendors, librarians and faculty can create a more positive future. 


\section{APPENDIX}

- How familiar, if at all, are you with e-books?

- What do you know about them?

- Have you used them in your classes? If so...

o What did you think of them?

- How often do you use them?

- What was student input about them?

- How likely are you to use them in the fall semester? If not, why not?

- Do you use e-books as textbooks? If not, why not?

o If not, have you ever considered using them? If not, why not?

- Have you personally used e-books in your research? If so, how often? Describe your experience with them. If not, why not?

- How would you find out if a book is available as an e-book?

- Let's say you are using a textbook in class. The textbook is available in print and as an e-book. Which would you assign? Would you give students the option to choose? Why or why not?

- Would the subject matter of the book affect your decision? If so, why?

- Would you have any concerns about choosing an e-book? If so, what are your concerns?

- What about a book that's not a textbook? Do you think students prefer print or ebooks?

- Do you see any advantages to using print rather than e-books? If so, what are the advantages? What about disadvantages?

- Do you see any advantages to using e-books rather than print books?

- Would you use e-books any differently than you use print books? In what ways? Why?

- What kind of information would you want about e-books before you decided to use them or use them more frequently?

- If you haven't tried them before, what could the library do to encourage you to try them?

\section{Acknowledgements}

The authors would like to thank our colleague, Sheila Hofstetter MLS, Health Sciences Librarian at ASU Libraries for reviewing this manuscript and providing very valuable feedback. We'd also like to thank Christopher Perry for his editing skills. Additionally, we are indebted to Michael Levine-Clark, Collections Librarian for the University of Denver, who shared invaluable data with us. 


\section{References}

Anuradha, K.T. \& Usha, H.S. 2006, "Use of e-books in an academic and research environment: A case study from the Indian Institute of Science", Program, vol. 40, no. 1, pp. 48-62.

Appleton, L. 2004, "The use of electronic books in midwifery education: the student perspective", Health Information \& Libraries Journal, vol. 21, no. 4, pp. 245-252.

Chu, H. 2003, "Electronic books: viewpoints from users and potential users", Library Hi Tech, vol. 21, no. 3, pp. 340-346.

Cox, J. 2004, "E-Books: Challenges and Opportunities", D-Lib Magazine, vol. 10, no. 10, pp. 1. [Online]. Available: http://www.dlib.org/dlib/october04/10contents.html [November 30, 2007]

Ebrary 2007, "2007 Global Faculty Survey E-book Survey"[Online]. Available: http://www.ebrary.com/corp/collateral/en/Survey/ebrary_eBook_survey_2007.pdf [November 30, 2007]

Ismail, R. \& Zainab, A.N. 2005, "The Pattern of E-Book Use Amongst Undergraduates in Malaysia: A Case of To Know Is To Use", Malaysian Journal of Library \& Information Science, vol. 10, no. 2, pp. 1-23.

Levine-Clark, M. 2007a. Personal communication, November, 2007.

Levine-Clark, M. 2007b, "Electronic books and the humanities: a survey at the University of Denver", Collection Building, vol. 26, no. 1, pp. 7-14.

Levine-Clark, M. 2006, "Electronic Book Usage: A Survey at the University of Denver", Portal, vol. 6, no. 3, pp. 285-299.

Office of the President, Arizona State University "This is our New American University: About [Online.] Available: http://mynew.asu.edu/about [2007, October 26]

Rowlands, I., Nicholas, D., Jamali, H., Huntington, P. 2007, What do faculty and students really think about e-books? [Online]. Available: http://www.homepages.ucl.ac.uk/ uczciro/findings.pdf [2007, October 4]

Shoaf, E.C. 2003, "Using a Professional Moderator in Library Focus Group Research", College \& Research Libraries, vol. 64, no. 2, pp. 124-132.

Walton, E.W. 2007, "Faculty and student perceptions of using e books in a small academic institution". In: ACRL Thirteenth National Conference Proceedings, Baltimore, MD. Chicago: American Library Association. 